\title{
Stimulating Effect of Gamma Radiation on some Active Compounds in Eggplant Fruits
}

\author{
Amina A. Aly", Noha E. Eliwa, Mohamed H. AbdEl-Megid \\ Natural Products Department, National Center for Radiation Research and Technology \\ (NCRRT), Atomic Energy Authority (AEA), P.O. 29, Nasr City, Cairo, Egypt.
}

\begin{abstract}
A FIELD experiment was performed to study the effect of gamma irradiation $(0.0,50$ and $100 \mathrm{~Gy})$ on growth parameters and bioactive compounds of different parts of eggplant. All growth parameters studied showed an increase when using a dose of 50Gy gamma rays. Also, 50Gy increased total phenolic contents $(2.140,4.039$ and $2.965 \mathrm{mg} / \mathrm{g}$ DW) for pulp, peel and whole fruits, respectively. A dose level at 50Gy increased flavonoid contents $(0.835,4.301$ and $3.166 \mathrm{mg} / \mathrm{g} \mathrm{DW}$ ) for pulp, peel and whole fruits, respectively. Moreover, tannin contents increased at a dose of 50Gy to $(5.853,7.94$ and $7.79 \mathrm{mg} / \mathrm{g}$ DW) for pulp, peel and whole fruits respectively; the highest contents were detected in peels followed by the whole fruits and the pulps. The DPPH radical scavenging activity of eggplant extracts varies according to the plant part. The antioxidant activity in the whole fruit was less than the peel and pulp while the highest antioxidant activity was in the peel. Otherwise, the amino acid and total soluble protein contents were higher in pulp in all treatments. Phenyl alanine ammonia-lyase (PAL) enzyme and polyphenol oxidase enzyme showed increases in their activities as gamma radiation increased to $50 \mathrm{~Gy}$, while increasing irradiation dose level to $100 \mathrm{~Gy}$ reduces both enzyme activities. FT-IR showed the appearance and disappearance of function group in control and irradiated plants. Meanwhile, the results confirmed the presence of $\mathrm{C}-\mathrm{H}$ stretching phenol $\left(1020 \mathrm{~cm}^{-1}\right)$, alkane C-H blending $\left(1450 \mathrm{~cm}^{-1}\right)$ and $\mathrm{O}-\mathrm{H}$ stretching, lipid at $\left(1450 \mathrm{~cm}^{-1}\right)$, and carbohydrate amino acids $\left(3940.39 \mathrm{~cm}^{-1}\right)$ in eggplant plants different parts control and irradiated.
\end{abstract}

Keywords: Gamma irradiation, Eggplant, Bioactive compounds, Fourier Transform Infrared (FTIR) spectroscopy.

\section{Introduction}

Eggplant (Solanumm elongena L.) is considered one of the most important and popular vegetable crop in Egypt, while in many other tropical and sub-tropical countries, it is considered as national diet. Eggplant fruits have high contents of carbohydrates, proteins and some minerals such as $\mathrm{Ca}, \mathrm{Mg}$, and $\mathrm{P}$ with a high content of minerals (El-Nemr et al., 2012) and have low calories $(25 \mathrm{kcal} / 100 \mathrm{~g})$. The world production of eggplant is about 50 million tons annually, and hence, it becomes the fifth most economically important solanaceous crop after potato, tomato, pepper and tobacco (Taher et al., 2017). The most common producing countries are China (28.4 million tons; $57 \%$ of world's total), India (13.4 million tons; $27 \%$ of world's total), Egypt (1.2 million tons), Turkey (0.82 million tons), and Iran (0.75 million tons).
Eggplant acquires its quality from its violet surface without defects, and absence of seed (Cantwell \& Suslow, 2009). Moreover, loss of cellular compartmentalization accelerates browning by increasing peroxide levels and oxygen partial pressure within the tissues, and by releasing phenolics found in the vacuoles, which are oxidized by polyphenol oxidases and peroxidases (Concelin et al., 2004). Polyphenols have received a great concern because of their strong powerful antioxidant properties. Also, they exist at a high concentration in many fruits and vegetables. Many researchers have confirmed that consuming fruits and vegetables which have high contents of polyphenols reduces the risk of coronary heart diseases, neurodegenerative diseases and certain forms of cancers (Hung et al., 2004), and acts as hepatoprotective (Akanitapichat et al., 2010), anti-inflammatory (Han et al., 2003) and antiallergic (Lee et al., 2001). The medicinal

\footnotetext{
"Corresponding author email: aly_amina@yahoo.co.uk DOI: 10.21608 /ejrsa.2019.10024.1066

Tel.: (+202) 22747413

Fax: (+202) 22749298

CThe National Information and Documentation Center (NIDOC)
} 
properties of Solanum melongena plant leaves are derived from its chemical constituents and its antioxidant property which are attributed to flavonoids. The terpenes (steroids) make it useful for bronchitis and also analgesic property is because of the alkaloids (Shrivastava et al., 2012). The whole eggplant fruits are one of the top ten vegetables in terms of oxygen radical absorbance capacity and antioxidant activity of entire fruits of eggplant was examined by various assays (Hanson et al., 2006), some researchers examined the skin (Azevedo et al., 2007) while others examined the pulp (Singh et al., 2009). Gamma rays are one type of ionizing radiation which reacts with atoms or molecules to produce free radicals in cells. These radicals can change essential constituents of plant cells. Gamma irradiation mostly influences the plant growth by alteration in production via cytology, biochemistry, physiology and morphogenetic of the cells (Rahimi \& Bahrani, 2011). Some studies confirmed preventive effects of greater exposure of gamma rays, while low doses of gamma rays stimulate seed germination of Pinus kesiya Gord, P. wallichiana, and Botanica orientalis (Thapa \& Jacks, 1999). Moreover, the stimulating effects of gamma irradiation were recorded to raise the flavonoid, alkaloid, phenolic compound, and antioxidant activity (Kim et al., 2006).

The relatively low doses of ionizing radiation on plant appeared in accelerating cell proliferation, germination rate, cell growth, enzyme activity, stress resistance and crop yields (El-Beltagi et al., 2011 b). The aim of this study is to investigate the effect of gamma irradiation on growth and bioactive compounds of eggplant different parts.

\section{Materials and Methods}

\section{Chemicals}

All reagents were obtained from SigmaAldrich S.p.A. (Milan, Italy) and had a high degree of purity (purity $>97 \%$ ).

\section{Materials}

In this study, eggplant seeds (EW7676) long type, deep purple were provided from Suez Canal Trade and Agricultural Company Cairo-Egypt.

\section{Irradiation treatments}

Seeds were divided into three groups; control and irradiated at dose levels 50 and 100Gy at dose rate $0.688 \mathrm{rad} / \mathrm{sec}$ from $\mathrm{Cs}^{137}$.
Non-irradiated and irradiated eggplant seeds were counted and put in petri dishes to calculate germination percentage.

One hundred of eggplant seeds were sown in pots $(7 \mathrm{~cm})$ containing three seeds each and $1: 1$ mixture of peat and perlite. After three weeks, plants were transferred to the soil to reach fruit stage. After 70 days from transferring to soil, four plants per replicate were randomly chosen to measure the growth parameters including plant height $(\mathrm{cm})$, root length $(\mathrm{cm})$, fruit length $(\mathrm{cm})$, fruit diameter $(\mathrm{cm})$, fresh and dry weight $(\mathrm{gm})$. A complete randomized block design (CRBD) with three replicates was used.

\section{Lypholization}

The eggplant fruits were separated into pulp, peel and whole fruit, weighed, chopped and homogenized under liquid nitrogen and weighed at a portion of 50-100g and then, lyophilized for $48 \mathrm{hr}$ (Virtis model 10-324), finally the dry weight was determined. The samples were ground to pass through a $0.5 \mathrm{~mm}$ sieve and stored at $-20^{\circ} \mathrm{C}$ until the bioactive substances were analyzed.

\section{Ethanolic extract}

The lyophilized samples of eggplant pulp, peel and whole fruit, $(2 \mathrm{~g})$ were extracted with $25 \mathrm{ml}$ of ethanol $80 \%$ at room temperature in the dark for $24 \mathrm{~h}$, followed by filtration through Whatman filter paper No.1. The residue was re-extracted in the same manner three times and the three filtrates were combined (Sobhy et al., 2009) and the final volume was concentrated to $25 \mathrm{ml}$.

\section{Total phenolic compounds}

Phenolic content was measured using the Folin-Denis reagent (Shahidi \& Naczk, 1995). Absorbance was measured at $765 \mathrm{~nm}$ using spectrophotomer (Jasco V-530). The results were expressed as $\mathrm{mg} / \mathrm{g}$ of gallic (GAE) equivalent of the dry weight of the extract.

\section{Flavonoids contents}

Flavonoids content was determined in the extracts by the aluminum chloride colorimetric assay (Marinova et al., 2005). The absorbance was measured against the blank at $510 \mathrm{~nm}$. Total flavonoids were expressed as mg quercetin (QE) equivalent/g dry weight of extract.

\section{Tannins content}

The content of tannins was determined 
according to a modified vanillin assay (Price et al., 1978). Tannin fractions were dissolved in ethanol $(0.5 \mathrm{mg} / \mathrm{ml})$. To $1 \mathrm{ml}$ of prepared solution, $5.0 \mathrm{ml}$ of vanillin- $\mathrm{HCl}$ reagent $(0.5 \mathrm{~g}$ vanillin in $4 \%$ hydrochloric acid in methanol (v/v) was added). Samples and controls (without vanillin) were allowed to stand for $20 \mathrm{~min}$ in darkness and then, absorbance at $500 \mathrm{~nm}$ was read. The total tannin content was expressed as tannic acid equivalents (mg/g dry weight of the extract).

\section{DPPH free radical scavenging activity}

The radical scavenging activity of the extracts against 2,2- Diphenyl-1-picryl hydrazyl (DPPH) radical was determined as described by Gulluce et al. (2004)

\section{Total free amino acids}

Total free amino acids were determined by the ninhydrin test, using the method outlined by Jayeraman (1985).

\section{Total soluble protein}

Total soluble protein was estimated using the method of Comassie Brilliant Blue G-250 according to the method of Bradford (1976).

\section{Total soluble sugars}

Total soluble sugars were determined by Phenol-Sulfuric acid method at $488 \mathrm{~nm}$ according to Dubois et al. (1956).

\section{Enzymes extraction}

Different parts of eggplant $(1.0 \mathrm{gm})$ of each fresh sample were homogenized in $100 \mathrm{mM}$ chilled sodium phosphate buffer ( $\mathrm{pH}$ 7.0) containing $0.1 \mathrm{mM}$ EDTA and $1 \%$ polyvinyl pyrrolidone (PVP) $(\mathrm{w} / \mathrm{v})$ at $4^{\circ} \mathrm{C}$. The extraction ratio was $4.0 \mathrm{ml}$ buffer for each one gram of samples. The homogenate was centrifuged at $15.000 \times \mathrm{g}$ for $15 \mathrm{~min}$ at $4^{\circ} \mathrm{C}$. Supernatant was used to measure the activities of phenylalanine ammonia-lyase (PAL) and polyphenol oxidase enzymes.

Assay of phenylalanine ammonia-lyase (PAL) activity

The activity of phenylalanine ammonialays was measured as the rate of conversion of L-phenylalanine to trans- cinnamic acid (He et al., 2001). The assay reaction mixture consists of $100 \mu \mathrm{l}$ crude enzyme extract and $900 \mu 1$ of 6 $\mu \mathrm{mol}$ L-Phenylalanine in $500 \mathrm{mM}$ Tris- $\mathrm{HCl}$ buffer $(\mathrm{pH}$ 8.5). The mixture was incubated at $37^{\circ} \mathrm{C}$ for $1 \mathrm{hr}$, the enzymatic reaction was stopped with $0.1 \mathrm{ml} 6 \mathrm{~N} \mathrm{HCl}$. The absorbance was measured by spectrophotometer at $290 \mathrm{~nm}$. The produced amount of trans-cinnamic acid formed was calculated using its extinction coefficient of $9630 \mathrm{M}^{-1} \mathrm{~cm}^{-1}$. The enzyme activity was expressed as unit $\mathrm{min}^{-1} \mathrm{mg}^{-1}$ protein.

\section{Polyphenol oxidase}

The activity of polyphenol oxidase (PPO) was assayed (Oktay et al., 1995). The reaction mixture consisted of $600 \mu \mathrm{l}$ catechol $(0.1 \mathrm{M})$ and $100 \mu 1$ enzyme extract and was completed to $3.0 \mathrm{ml}$ with $0.1 \mathrm{M}$ phosphate buffer $\mathrm{pH} 7$. The absorbance was registered at $420 \mathrm{~nm}$ by spectrophotometer. One unit of PPO activity was defined as the amount of enzyme that causes an increase in absorbance of $0.001 \mathrm{~min}^{-1} \mathrm{ml}^{-1}$. The enzyme activity was expressed as unit $\mathrm{min}^{-1} \mathrm{mg}^{-1}$ protein.

\section{Fourier transform infrared (FT-IR)}

Fourier transform infrared (FT-IR) was used to identify the characteristic functional groups in $2.0 \mathrm{mg}$ of the lyophilized different parts of eggplant. The lyophilized was measured between 4000 to $400 \mathrm{~cm}^{-1}$ at a resolution of $4 \mathrm{~cm}^{-1}$, using a Bruker Vertex 70 FT-IR spectrometer equipped with HYPERION ${ }^{\mathrm{TM}}$ series microscope (Bruke Optik GmbH, Ettingen, Germany).

\section{Statistical analysis}

Data were analyzed with statistical software analysis of variance (ANOVA) and Duncan's multiple range method was used to compare any significant differences between treatments. Values were expressed as means \pm standard deviations. Differences were considered significant at $\mathrm{P}<0.05$ (Duncan, 1955).

\section{Results}

Effect of gamma irradiation on vegetative growth of eggplant

Data presented in Table 1 show the vegetative parameters of eggplant as affected by gamma irradiation $(0.0,50.0$ and $100.0 \mathrm{~Gy})$. It is clear from the results that 50Gy enhanced the growth of eggplant in all growth parameters studied (i.e. germination percentage, plant height, root length, fruit length, fruit diameters, fresh weight and dry weight) $(99 \%, 64.5 \mathrm{~cm}, 27 \mathrm{~cm}, 16.89 \mathrm{~cm}$, $12.6 \mathrm{~cm}, 65.08 \mathrm{~g}$ and $5.4 \mathrm{~g}$ ), respectively. 
TABLE 1. Vegetative growth traits of eggplant under the effect of gamma irradiation.

\begin{tabular}{lccccccc}
\hline $\begin{array}{l}\text { Irradiation } \\
\text { dose level } \\
(\mathbf{G y})\end{array}$ & $\begin{array}{c}\text { Germination } \\
\mathbf{\%}\end{array}$ & $\begin{array}{c}\text { Plant } \\
\text { height } \\
\mathbf{( c m )}\end{array}$ & $\begin{array}{c}\text { Root } \\
\text { length } \\
\mathbf{( c m )}\end{array}$ & $\begin{array}{c}\text { Fruit } \\
\text { length } \\
\mathbf{( c m )}\end{array}$ & $\begin{array}{c}\text { Fruit } \\
\text { diameter } \\
\mathbf{( c m )}\end{array}$ & $\begin{array}{c}\text { Fresh } \\
\text { weight of } \\
\text { fruit (g) }\end{array}$ & $\begin{array}{c}\text { Dry } \\
\text { weight of } \\
\text { fruit (g) }\end{array}$ \\
\hline Control $(0.0)$ & $93.5^{\mathrm{B}} \pm 1.5$ & $53.8^{\mathrm{B}} \pm 1.1$ & $22^{\mathrm{B}} \pm 1.2$ & $14.01^{\mathrm{B}} \pm 1.9$ & $9.5^{\mathrm{C}} \pm 1.10$ & $44.31^{\mathrm{C}} \pm 10.9$ & $3.4^{\mathrm{B}} \pm 0.9$ \\
50 & $99^{\mathrm{A}} \pm 1.20$ & $64.5^{\mathrm{A}} \pm 1.3$ & $27^{\mathrm{A}} \pm 2.3$ & $16.89^{\mathrm{A}} \pm 1.7$ & $12.6^{\mathrm{A}} \pm 1.13$ & $65.08^{\mathrm{A}} \pm 9.1$ & $5.4^{\mathrm{A}} \pm 0.8$ \\
100 & $82.5^{\mathrm{C}} \pm 1.2$ & $40.2^{\mathrm{C}} \pm 1.1$ & $25^{\mathrm{A}} \pm 1.6$ & $13.10^{\mathrm{C}} \pm 1.8$ & $11.20^{\mathrm{B}} \pm 1.14$ & $57.35^{\mathrm{B}} \pm 10.4$ & $4.6^{\mathrm{A}} \pm 0.7$ \\
LSD & 1.68 & 1.3761 & 2.8255 & 0.346 & 0.2083 & 0.1142 & 0.9374 \\
\hline
\end{tabular}

a,b,c. Means within same column followed by different letters are significantly different at $\mathrm{P}<0.05$. Values are means of three replicates $( \pm \mathrm{SD})$.

\section{Total phenolic compounds}

Effect of gamma irradiation on phenolic compounds contents of eggplant is illustrated in Table 2, it is clear that gamma irradiation increased phenolic compounds and the maximum increase was observed in peel parts of eggplants at a dose level of $50 \mathrm{~Gy}(4.039 \mathrm{mg} / \mathrm{g} \mathrm{DW})$ followed by whole fruits $(2.965 \mathrm{mg} / \mathrm{g} \mathrm{DW})$. The pulp of eggplants showed the lowest phenolic content. While increasing gamma dose level to 100Gy showed reduction in phenolic contents in all parts of eggplants.

\section{Flavonoids contents}

Regarding flavonoid content, it is revealed that gamma irradiation dose level 50Gy increased flavonoids content of eggplants. In pulp part flavonoids contents were increased from $0.595 \mathrm{mg} / \mathrm{g}$ DW for control to $0.835 \mathrm{mg} / \mathrm{g}$ DW at $50 \mathrm{~Gy}$ and decreased to $0.610 \mathrm{mg} / \mathrm{g} \mathrm{DW}$ at $100 \mathrm{~Gy}$ (Table 2).

\section{Tannins content}

Results shown in Table 2 illustrated that gamma irradiation showed the same trend on tannins contents of eggplants hence, gamma irradiation at a dose level of 50Gy increased tannin contents of eggplants. Whole fruit of 50Gy irradiated eggplant showed an increase in tannins content $(7.797 \mathrm{mg} / \mathrm{g} \mathrm{DW})$, while at $100 \mathrm{~Gy}$ the whole fruit of plant gave $6.180 \mathrm{mg} / \mathrm{g}$ DW.

Antioxidant activity by scavenging activity on DPPH radical

The DPPH radical is usually used as a substrate to evaluate the antioxidative action of antioxidants by determining the free radical scavenging ability of various samples (Amarowicz et al., 2004).

Table 2 shows the DPPH radical scavenging activity of eggplant extracts of different parts. The antioxidant activity in the whole fruit was lesser than the peel and higher than pulp while the highest antioxidant activity was observed in the peel $(71.41,76.40$ and $73.02 \%)$ at $0.0,50$ and 100 Gy, respectively.

\section{Total free amino acids}

Table 3 shows the content of amino acids (mg/g DW) in eggplant affected by gamma rays. The amino acid content was clearly the highest in the pulp in all treatments, where it was 3.11, 5.44 and $3.56 \mathrm{mg} / \mathrm{g}$ DW at dose level 0.0, 50 and $100 \mathrm{~Gy}$, respectively. The dose of 50Gy gave the highest amino acid contents for the different parts (pulp, peel and whole fruit) of eggplant.

\section{Total soluble protein}

Data in Table 3 shows that total soluble protein content in different parts of eggplant is affected by irradiation, which was increased by irradiation dose level of 50Gy. This dose gave the highest contents $(17.87,16.04$ and $11.61 \mathrm{mg} / \mathrm{g}$ DW) in the different parts (pulp, whole fruit and peel, respectively).

\section{Total soluble sugars}

Results in Table 3 shows the influence of gamma rays on the total soluble sugars contents (mg/g DW) in different parts of eggplant. The observed data showed that there were variable patterns in total soluble sugars content in the tested plant parts as affected by gamma rays. The dose level of 50Gy increased the total soluble sugars content in all plant parts while decreased by increasing the dose level of 100Gy. Also, the pulp gave the highest content of total soluble sugars in all treatments, as it was $4.99 \mathrm{mg} / \mathrm{g} \mathrm{DW}$ at dose of $50 \mathrm{~Gy}$ followed by whole fruit $(3.89 \mathrm{mg} / \mathrm{g}$ DW). 
TABLE 2 . Phenolic, flavonoid tannin contents $(\mathrm{mg} / \mathrm{g} \mathrm{DW})$ and scavenging activity percentage of different parts of eggplant as affected by gamma irradiation.

\begin{tabular}{|c|c|c|c|c|c|}
\hline $\begin{array}{l}\text { Irradiation } \\
\text { dose level } \\
\text { (Gy) }\end{array}$ & Plant part & Phenols & Flavonoids & Tannins & $\begin{array}{c}\text { Scavenging activity } \\
(\%)\end{array}$ \\
\hline \multirow{3}{*}{$\begin{array}{l}\text { Control } \\
(0.0 \mathrm{~Gy})\end{array}$} & Pulp & $0.304^{\perp} \pm 0.884$ & $0.595^{\mathrm{I}} \pm 0.042$ & $1.249^{I} \pm 0.894$ & $52.48^{\mathrm{H}} \pm 14.6$ \\
\hline & Peel & $2.481^{\mathrm{D}} \pm 0.105$ & $1.438^{\mathrm{D}} \pm 0.900$ & $1.867^{\mathrm{G}} \pm 0.960$ & $71.41^{\mathrm{C}_{ \pm}} 5.0$ \\
\hline & Whole fruit & $0.370^{\mathrm{H}} \pm 0.151$ & $0.735^{\mathrm{G}} \pm 0.532$ & $1.712^{\mathrm{H}} \pm 0.850$ & $59.53^{\mathrm{F}} \pm 4.7$ \\
\hline \multirow{3}{*}{$50 \mathrm{~Gy}$} & Pulp & $2.140^{\mathrm{E}} \pm 0.302$ & $0.835^{\mathrm{E}} \pm 0.057$ & $5.853^{\mathrm{E}} \pm 0.624$ & $59.02^{\mathrm{F}} \pm 7.4$ \\
\hline & Peel & $4.039^{\mathrm{A}} \pm 0.470$ & $4.301^{\mathrm{A}} \pm 0.990$ & $7.948^{\mathrm{A}} \pm 0.954$ & $76.40^{\mathrm{A}} \pm 6.1$ \\
\hline & Whole fruit & $2.965^{\mathrm{C}} \pm 0.323$ & $3.166^{\mathrm{C}} \pm 0.892$ & $7.797^{\mathrm{B}} \pm 0.907$ & $66.99^{\mathrm{D}} \pm 8.0$ \\
\hline \multirow{3}{*}{$100 \mathrm{~Gy}$} & Pulp & $0.652^{\mathrm{G}} \pm 0.990$ & $0.610^{\mathrm{H}} \pm 0.490$ & $4.943^{\mathrm{F}} \pm 0.748$ & $56.89^{\mathrm{G}} \pm 7.8$ \\
\hline & Peel & $3.641^{\mathrm{B}} \pm 0.783$ & $3.656^{\mathrm{B}} \pm 0.944$ & $6.353^{\mathrm{C}} \pm 0.904$ & $73.02^{\mathrm{B}} \pm 7.4$ \\
\hline & Whole fruit & $1.618^{\mathrm{F}} \pm 0.887$ & $0.752^{\mathrm{F}} \pm 0.840$ & $6.180^{\mathrm{D}} \pm 0.839$ & $63.39^{\mathrm{E}} \pm 8.1$ \\
\hline LSD & & 0.0064 & 0.0117 & 0.0066 & 0.7988 \\
\hline
\end{tabular}

a,b,c. Means within same column followed by different letters are significantly different at $\mathrm{P}<0.05$. Values are means of three replicates $( \pm \mathrm{SD})$.

TABLE 3. Effect of gamma rays on total free amino acids content, total soluble protein content and total soluble sugars content (mg/g DW) of eggplant different parts.

\begin{tabular}{lcccc}
\hline $\begin{array}{l}\text { Irradiation } \\
\text { dose level } \\
(\text { Gy })\end{array}$ & Plant part & Amino acids & Total soluble protein & $\begin{array}{c}\text { Total soluble } \\
\text { sugar }\end{array}$ \\
\hline Control & Pulp & $3.11^{\mathrm{D}} \pm 0.90$ & $15.87^{\mathrm{C}} \pm 1.61$ & $3.76^{\mathrm{C}} \pm 0.77$ \\
$(0.0 \mathrm{~Gy})$ & Peel & $1.24^{\mathrm{H}} \pm 0.72$ & $9.63^{\mathrm{H}} \pm 1.51$ & $1.80^{\mathrm{G}} \pm 0.50$ \\
& Whole fruit & $2.27^{\mathrm{F}} \pm 0.89$ & $13.67^{\mathrm{E}} \pm 2.66$ & $2.94^{\mathrm{E}} \pm 0.90$ \\
& Pulp & $5.44^{\mathrm{A}} \pm 0.62$ & $17.87^{\mathrm{A}} \pm 2.57$ & $4.99^{\mathrm{A}} \pm 1.00$ \\
50 Gy & Peel & $2.73^{\mathrm{E}} \pm 0.94$ & $11.61^{\mathrm{F}} \pm 1.52$ & $2.79^{\mathrm{E}} \pm 0.700$ \\
& Whole fruit & $4.41^{\mathrm{B}} \pm 0.72$ & $16.04^{\mathrm{C}} \pm 2.33$ & $3.89^{\mathrm{C}} \pm 1.30$ \\
$100 \mathrm{~Gy}$ & Pulp & $3.56^{\mathrm{C}} \pm 0.83$ & $16.57^{\mathrm{B}} \pm 2.42$ & $4.70^{\mathrm{B}} \pm 1.40$ \\
& Peel & $1.59^{\mathrm{G}} \pm 0.90$ & $10.23^{\mathrm{G}} \pm 1.58$ & $2.07^{\mathrm{F}} \pm 0.80$ \\
L.S.D. & Whole fruit & $2.93^{\mathrm{DE}} \pm 0.61$ & $14.68^{\mathrm{D}} \pm 1.64$ & $3.37^{\mathrm{D}} \pm 0.58$ \\
\hline
\end{tabular}

a,b,c.Means within same column followed by different letters are significantly different at $\mathrm{P}<0.05$. Values are means of three replicates $( \pm \mathrm{SD})$.

\section{Enzyme activity}

Enzyme activity of different parts of eggplant under the effect of gamma irradiation is revealed in Fig. 1, and 2. Phenyl alanine ammonia-lyase (PAL) and polyphenol oxidase enzymes showed increase in the activity as gamma irradiation increased from 0.0 to 50Gy while increasing irradiation dose level to $100 \mathrm{~Gy}$ reduced both enzymes activity. Peel parts of eggplant gave the highest activity among all studied parts.

\section{FT-IR analysis}

The FT-IR spectroscopic analysis technique was used for estimating the pattern of organic and inorganic complexes in plants. In the present study, the FT-IR showed the presence of phyto constituents in the lyophilized powder of different parts of eggplant as affected by gamma irradiation. The preparatory phytochemical profile (Table 4) confirmed the representative FT-IR spectra obtained from the eggplant different parts in the $590-4000 \mathrm{~cm}^{-1}$ region. 
LSD $=0.0634$

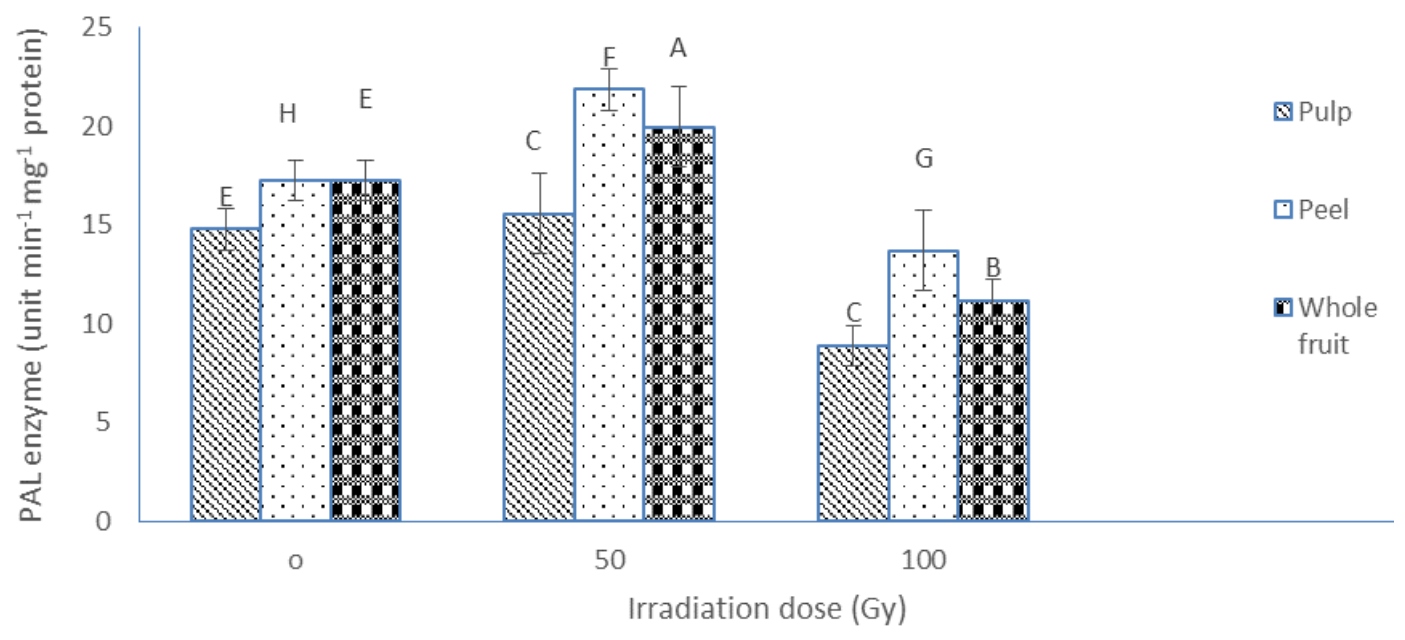

Fig. 1. Phenylalanine ammonia-lyase (PAL) enzymes activity (unit $\mathrm{min}^{-1} \mathrm{mg}^{-1}$ protein) in different parts of eggplant as affected by gamma irradiation [Different letters indicate statistically significant difference at $\mathbf{P} \leq \mathbf{0 . 0 5}$. Vertical bars show standard deviation $(n=3)$.]

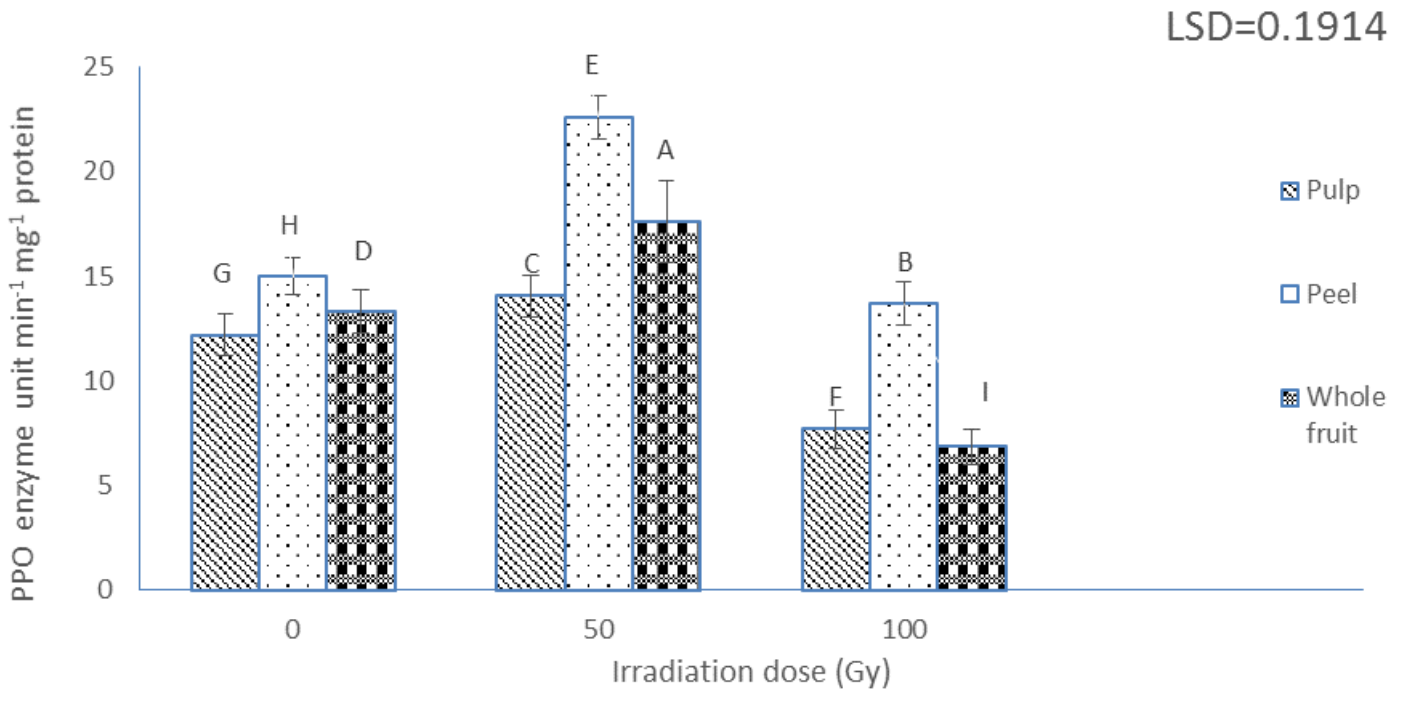

Fig. 2. Polyphenol oxidase enzymes activity (unit $\mathrm{min}^{-1} \mathrm{mg}^{-1}$ protein) in different parts of eggplant as affected by gamma irradiation [Different letters indicate statistically significant difference at $\mathbf{P} \leq \mathbf{0 . 0 5}$. Vertical bars show standard deviation $(n=3$ ].

The FT-IR analysis of eggplant different parts revealed that bromo compound $\left(592.20 \mathrm{~cm}^{1}\right)$ appeared only in peel part of 50 Gy treated eggplants. Halogen-alkyl halide group $\left(604.39-641.94 \mathrm{~cm}^{-1}\right)$ appears in all eggplant parts while disappeared in 100Gy irradiated samples. Nitrogenous compounds $\quad \mathrm{N}-\mathrm{H}$ stretching $\left(1661.16 \mathrm{~cm}^{-1}\right)$ disappeared in peel part of eggplant irradiated at 50Gy. Cycloalkane (2590.19) appeared in all parts of non-irradiated and irradiated plant except for pulp part of non-irradiated plants. Otherwise $\mathrm{O}-\mathrm{H}$ stretching and carbohydrate amino acids $\left(3940.39 \mathrm{~cm}^{-1}\right)$ appeared in pulp part and whole fruit of 50Gy irradiated eggplants. The obtained data confirmed the presence of $\mathrm{C}-\mathrm{H}$ stretching phenol, $-\mathrm{C}-\mathrm{O}-\mathrm{C}$ pyranose ring $\left(1020 \mathrm{~cm}^{-1}\right)$, lipid at $\left(1450 \mathrm{~cm}^{-1}\right)$, ester carboxyl-COOR (2037.492182.64) and $\mathrm{C} \equiv \mathrm{C}$ alkyne $\left(2831.17-2913.06 \mathrm{~cm}^{-1}\right)$ in all eggplant parts. 


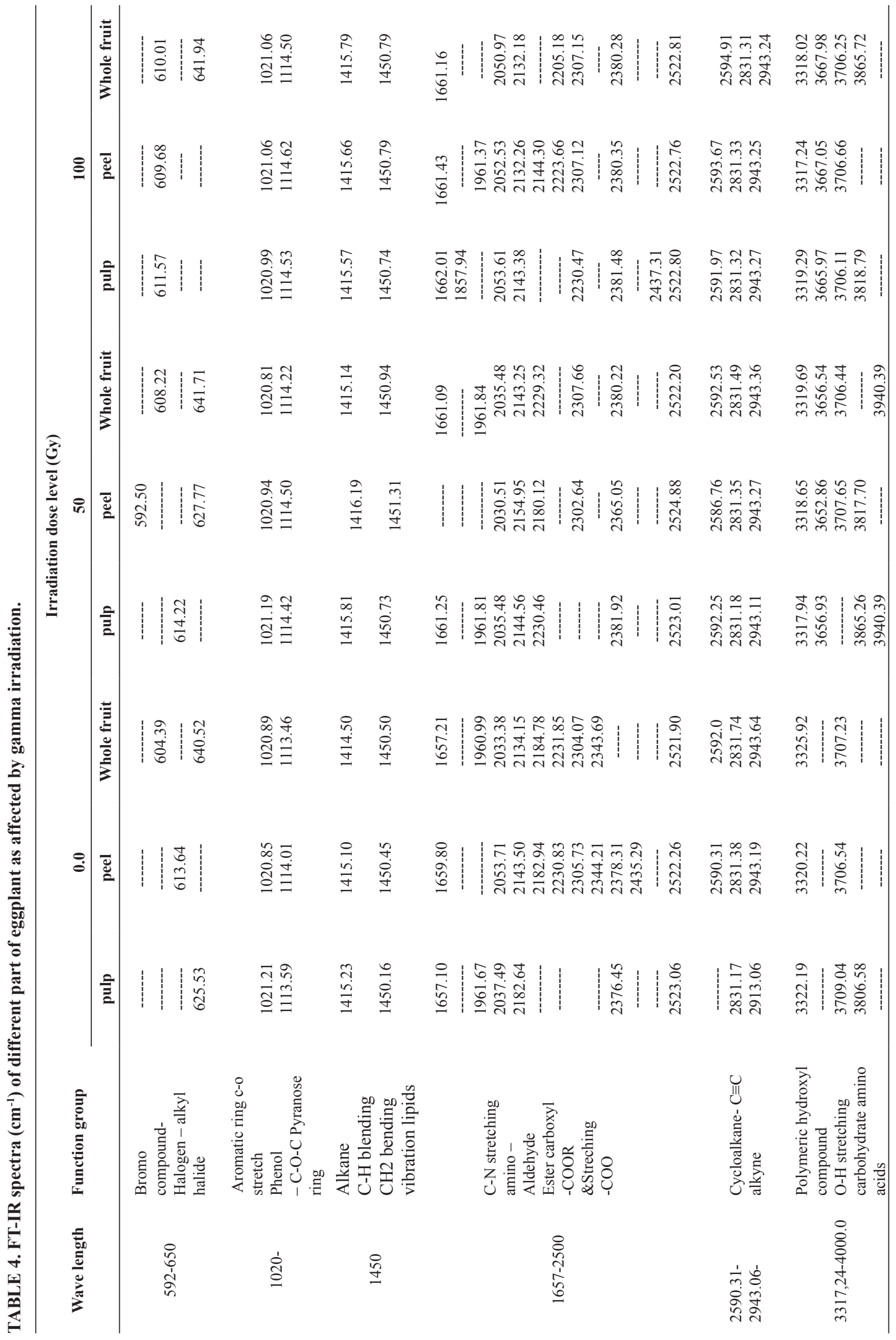

Egypt. J. Rad. Sci. Applic. 32, No.1 (2019) 


\section{Discussion}

Field experiment was performed to study the effect of gamma irradiation $(0.0,50,100 \mathrm{~Gy})$ on growth parameters and bioactive compounds of different parts of eggplant. All the studied growth parameters showed increase at 50Gy gamma rays dose. Changes in the germination percentage were found to attribute to gamma ray treatments. The stimulating causes by gamma ray on germination may be certified to the activation of RNA or protein synthesis, which occurred during the early stage of germination after seeds irradiation (Abdel-Hady et al., 2008). Germination starts with the uptake of water by dry seeds (Manz et al., 2005), while, other factors, are related to plant characteristics (e.g., species, cultivar, stage of development, tissue architecture, and genome organization) and some are related to radiation features (e.g., quality, dose, duration of exposure may significantly modify germination (Jan et al., 2012). The energy of ionizing radiation absorbed by seeds is changed to ROS that can present sometimes after irradiation in the air-dry seeds. However, when water enters to the seed, ROS become mobile and reacts rapidly (Bailly et al., 2008). The application of 100Gy decrease seed germination rate to $50 \%$ on all 5 eggplant genotypes studied (Arunal et al., 2010). A high dose of gamma rays decreased germination rate and plant survival percentage of Solanum nigrum L. sp. villosum (Ojiewo et al., 2005).

As for phenolic contents, 50Gy increased total phenolic contents for pulp, peel and whole fruits. A study on ionizing radiation, showed that an increase in the level of the total phenolic compounds were found (Behgar et al., 2011). Also, the application of gamma irradiation at dose levels of 25Gy and 200Gy significantly increased the phenolic content compared to control ones in Pterocarpus santalinus (Akshatha \& Chandrashekar, 2013). Phenolic content increased by increasing irradiation dose level in wheat grains (Aly et al., 2018). On the contrary, other researcher revealed that gamma irradiation reduced the content of phenolic compounds in plants (Bhat \& Sridhar, 2008). The effects of ionizing irradiation on tannins and phenolic compounds depend mainly on dose level (De Toledo et al., 2007). Universally, gamma radiation affect differently on the different phenolic compounds present in different plant materials. Gamma irradiation can stimulate the bioactivity of irradiated plants, depending on the modifications in the structure of different antioxidant molecules and/or breaking some chemical bonds (Pereira et al., 2015).

Phytochemical constituents such as flavonoid, phenol, and alkaloid have considerable effect on fodder quality. Phytochemical measurement showed that phenol and flavonoid contents (in leaves) and alkaloid (in seeds) of sainfoin change as affected by gamma irradiation (Mohajer et al., 2014). Similar to the present results, the phenolic acids of plant metabolites in soybean samples increased with gamma irradiation at levels ranging from 50 to $150 \mathrm{~Gy}$ (Variyar et al., 2004). Eggplant peel had a higher content of phenolic compounds, and it was about two and four times greater than that in eggplant pulp (Ji et al., 2011).

Flavonoids are a class of secondary plant metabolites with significant antioxidant and chelating properties and its antioxidant activity depends on the structure and substitution pattern of hydroxyl groups (Sharififar et al., 2009). Ionizing radiation reduced flavonoids content in chestnut, suggesting that these compounds may be sensitive to ionizing radiation (Carocho et al., 2012). Phenolic compounds of Ananas comosus, after the irradiation process above 150Gy, showed a higher tannins content, a type of polyphenol (Silva et al., 2007).

The destructive processes of oxidation and $\gamma$-irradiation are capable of breaking the chemical bonds of polyphenols, thereby releasing soluble phenols of low molecular weights, leading to an increase of antioxidant-rich phenolics (Adamo et al., 2004). A positive correlation between phenols and antioxidants has also been suggested (Harrison $\&$ Were, 2007). Gamma radiation was reported to induce oxidative stress with overproduction of reactive oxygen species (ROS) such as superoxide radicals, hydroxyl radicals and hydrogen peroxide. They react rapidly with almost all structural and functional organic molecules, including proteins, lipids and nucleic acids causing disturbance of cellular metabolism (Ashraf, 2009). The pool of free amino acids increased even at low doses of irradiation. The increase in amino acid concentration was attributed to the increase in protein content, which played an important role in DNA repair mechanism (Yu et al., 2016). The important role of protein synthesis for resistance of gamma rays, $\mathrm{UV}$ irradiation and $\mathrm{H}_{2} \mathrm{O}_{2}$ oxidative stress has been demonstrated by postulating newly synthesized proteins called "heat shock proteins", 
which help living cells to defend against the stress (Abo-Shady et al., 2008).

Simple organic molecules such as sugars, free amino acids and total soluble phenols may act as on osmoticum for the regulation of plants osmosis under saline soil conditions. Phenolic compounds accumulation could be a cellular adaptive mechanism for scavenging oxygen free radicals that were formed during stress conditions and this free radical scavenger could be oxidized for preventing subcellular damages (Tekam et al., 2014). It is well known that plants under stress may accumulate small molecular mass proteins that could be used as a source of storage nitrogen that could be mobilized after stress relief or removal. Additionally, these proteins could also have a role in osmotic adjustment (Neto et al., 2009).

The increase in PAL enzyme activity caused by irradiation treatment could also have resulted in an increase of total phenolics. As regulation of PAL activity is important in modulating phenylpropanoid biosynthesis in plants, plant phenolics are formed through phenylpropanoid metabolism. Similar observation has been reported earlier in citrus peel (Oufedjikh et al., 2000). Gamma irradiation, at different dose levels, increased the activity of polyphenol oxidase in garlic plants. The maximum activity was recorded at an irradiation dose of $70 \mathrm{~Gy}$ compared with the control, in green onion (Jimenez et al., 2011). On the other hand, other study indicated no significant differences in the PPO activity after the irradiation dose (Falguera et al., 2011).

The spectroscopic FT-IR analysis showed the appearance and disappearance of function group and metabolites in control and irradiated eggplant different parts. Dalavi \& Patil (2016) declared that the absorption spectra of Solanum anguivi fresh root extract represented the occurrence of alcohols and phenol compounds at $3618.77 \mathrm{~cm}^{-1}$, amine and amide compounds at $3333.36 \mathrm{~cm}^{-1}$, alkanes at 2940.91 and $2832.92 \mathrm{~cm}^{-1}$, amino acids at 1634.38 $\mathrm{cm}^{-1}$. The same author observed peaks at 1509.99 , $1445.39,1380.78,1273.75,1103.08,1017.27$, and $924.7 \mathrm{~cm}^{-1}$ indicated nitro compounds, aromatics, alcohols, carboxylic acids, esters, ethers, alkyl halides, ketone, aliphatic amines and ethers collectively. The metabolites screened such as phenols, amino acids, alkaloids, carbohydrates, amines, carboxylic acid, alkenes, proteins, sulphur compounds, and lipids were proved to exist in
Solanum tuberosum (Taoutaou et al., 2010). This was correlated with the FT-IR spectroscopic analysis in the whole plant extracts of Allium sativum (Garlic) which revealed the presence of phytochemicals such as alkaloids, proteins, lipids, oils, flavanoids, gums, phenols, saponins, steroids, tannins, and terpenoids (Nagarajan \& Ramesh Kumar, 2017). Otherwise, FT-IR analysis of the crude powder and dry ethanolic extracts of Albizia lebbeck leaves proved the presence of alcohols, phenols, alkanes, carboxylic acids, aromatics, ketones, and alkyl halides (Bobby \& Wesely, 2012).

\section{Conclusion}

Gamma irradiation can be used for enhancing the crops productivity and also increase the secondary metabolites which have a commercial importance and a high value. The current study revealed that gamma irradiation at a dose level of 50Gy enhanced the growth parameters such as germination percentage, plant height, root length, fruit length and fruit diameter. Likewise, this dose increased the total phenolic, flavonoid and tannin contents for pulp, peel and whole fruits in comparison to the $100 \mathrm{~Gy}$ dose level. It is worth mentioning that the activity of phenyl alanine ammonia-lyase (PAL) enzyme and poly phenol oxidase enzyme increased by applying gamma irradiation dose level of 50Gy. While increasing irradiation dose level to $100 \mathrm{~Gy}$ reduces both enzyme activities. The result of the present study also showed that FTIR spectroscopy is a valuable technique to fingerprint and to analyze the different biomolecules in the plants based on the peak values and functional groups obtained. It could be concluded that low doses of gamma irradiation have stimulating effect on eggplants.

Acknowledgements: The authors would like to thank the Atomic Energy Authority for supporting and funding this study. Thanks should also extend to the central laboratories at the National Center for Radiation Research and Technology for their help in running FT-IR analysis. Finally, the authors would like to thank the reviewers for their counteractive observations and comments that contributed to improve this study.

Conflict of interest: The authors declare that there is no conflict of interests regarding the publication of this paper. 


\section{References}

Abdel-Hady, M.S., Okasha, E.M. and Soliman, S.S.A. (2008) Effect of gamma radiation and gibberellic acid on germination and alkaloid production in Atropa belladonna. Aust. J. Basic. Appl. Sci. 2(3), 401-405.

Abo-Shady, A.M., El-Naggar, A.H., El-Sheekh, M. and Abomohra, A. (2008) Impact of UV-B radiation on antioxidant enzymes and protein electrophoretic pattern of the green alga Chlorococcum sp. Ann. Microbiol. 58(2), 195-201.

Adamo, M., Capitani, D., Mannina, L., Cristinzio, M., Ragni, P. and Tata, A. (2004) Truffles decontamination treatment by ionizing radiation. Rad. Physics and Chem. 71, 165-168.

Akanitapichat, P., Phraibung, K. and Nuchklang, K. (2010) Antioxidant and hepatoprotective activities of five eggplant varieties. Food Chem. Toxicol. 48(10), 3017-3021.

Akshatha and Chandrashekar, K.R. (2013) Effect of gamma irradiation on germination growth and biochemical parameters of Pterocarpus santalinus, an endangered species of Eastern Ghats. Euro. J. Exp. Bio. 3(2), 266-270.

Aly, A.A, Maraei, R.W and Ayadi, S. (2018) Some biochemical changes in two Egyptian bread wheat cultivars in response to gamma irradiation and salt stress. Bulg. J. Agri. Sci. 24(1), 50-59.

Amarowicz, R., Pegg, R..B., Rahim-Moghaddam, P., Barl, B. and Weil, J.A. (2004) Free radicalscavenging capacity and antioxidant activity of selected plant species from the Canadian prairies. Food Chem. 84, 551-562.

Arunal, J., Prakash, M. and Sunil Kumar, B. (2010) Studies on effect of physical and chemical mutagens on seedling characters in brinjal (Solanum melongena L.). Int. J. Curr. Res. 3, 038-041.

Ashraf, M. (2009) Biotechnological approach of improving plant salt tolerance using antioxidants as markers. Biotechnol. Adv. 27, 84-93.

Azevedo, L., de Lima, P.L.A. and Gomes, J.C. (2007) Differential response related to genotoxicity between eggplant (Solanum melanogena) skin aqueous extract and its main purified anthocyanin (delphinidin) in vivo. Food Chem. Toxicol. 45, 852858.

Bailly, C., El-Maarouf-Bouteau, H. and Corbineau, F. (2008) From intracellular signaling networks to cell death: the dual role of reactive oxygen species in seed physiology. C R Biol. 331, 806e 814 .

Behgar, M., Ghasemi, S. and Naseria, A. (2011) Gamma radiation effects on phenolics, antioxidants activity and in vitro digestion of pistachio (Pistachia vera) hull. Radiat. Phys. Chem. 80, 963-967.

Bhat, R. and Sridhar, K.R. (2008) Nutritional quality evaluation of electron beam-irradiated lotus (Nelumbo nucifera) seeds. Food Chem. 107, 174184.

Bobby, M.A and Wesely, E.G. (2012) Johnson M. FTIR studies on the leaves of Albizia lebbeck Benth. Int. J. Pharm. Pharm. Sci. 4(3), 293-296.

Bradford, M.M. (1976) A rapid and sensitive method for the quantification of microgram quantities of protein utilizing the principle of protein-dye binding. Anal. Biochem. 72, 248-254.

Cantwell, M. and Suslow, T.V. (2009) Eggplant: recommendations for maintaining postharvest quality.http:/ /postharvest. ucdavis. edu/Produce/ ProduceFacts/Veg/eggplant.shtml

Carocho, M., Antonio, A.L. and Barros, L. (2012) Comparative effects of gamma and electron beam irradiation on the antioxidant potential of Portuguese chestnuts (Castanea sativa Mill.). Food Chem. Toxicol. 50, 3452-3455.

Concelin, A., Ãnon, M.C. and Chaves, A.R. (2004) Characterization and changes in polyphenol oxidase from eggplant fruit (Solanum melongena L.) during storage at low temperature. Food Chem. 88, 17-24.

Dalavi, C. and Patil, S. (2016) FTIR spectroscopic screening of phytochemicals of two medicinally important species of solanum used in preparation of Dashmula formulation. Int. J. Pharm. Sci. Rev. Res. 19, 112-120.

De Toledo, T., Canniatti-Brazaca, S. and Arthur, V. (2007) Effects of gamm radiation on total phenolics, trypsin and tannin inhibitors in soybean grains. Radiat. Phys. Chem. 76, 1653-1656. 
Dubois, M., Smith, F., Gilles, K.A., Hamilton, J.K. and Rebers, P.A. (1956) Colorimetric mothod for determination of sugars and related substances. Analytical Chem. 28, 350-356.

Duncan, B.D. (1995) Multiple range and multiple F tests. Biometrics, 11,1.

El-Beltagi, H.S., Ahmed, O.K. and El-Desouky, W. (2011) Effect of low doses $\gamma$-irradiation on oxidative stress and secondary metabolites production of rosemary (Rosmarinus officinalis L.) callus culture. Radiat. Phys. Chem. 80, 968-976.

El-Nemr, M.A., El-Desuki, M. and Fawzy, Z.F. (2012) Yield and fruit quality of eggplant as affected by NPK sources and micronutrient application. $J$. Appl. Sci. Res. 8, 1351-1357.

Falguera, V., Pagán, J. and Ibarz, A. (2011) Effect of UV irradiation on enzymatic activities and physicochemical properties of apple juices from different varieties. LWT - Food Sci Technol. 44, 115-119.

Gulluce, M., Sokmen, M., Sahin, F., Sokmen, A., Adiguzel, A. and Ozer, H. (2004) Biological activities of the essential oil and methanolic extract of Micromeria fruticosa (L.) Druce ssp. serpy llifolia (Bieb) $\mathrm{PH}$ davis plants from the Eastern Anatolia region of Turkey. J. Sci. Food Agric. 84, 735.

Han, S.W., Tae, J. and Kim, J.A. (2003) The aqueous extract of Solanum melongena inhibits PAR2 agonist-induced inflammation. Clin. Chim. Acta, 328, 39-44.

Hanson, P.M., Yang, R.Y. and Tsou, S.C.S. (2006) Diversity in eggplant (Solanum melongena) for superoxide scavenging activity, total phenolics, and ascorbic acid. J. Food Compos. Anal. 19, 594-600.

Harrison, K. and Were, L.M. (2007) Effect of gamma irradiation on total phenolic content yield and antioxidant capacity of almond skin extracts. Food Chem. 102, 932-937.

He, C.Y., Hsiang, T. and Wolyn, D.J. (2001) Activation of defense responses to Fusarium infection in Asparagus densiflorus. Eur. J. Plant Patho. 10, 473-483.

Hung, H.C., Joshipura, K.J. and Jiang, R. (2004) Fruit and vegetable intake and risk of major chronic disease. Natl. Cancer Inst. 96(21), 1577-1584.

Jan, S., Parween, T. and Siddiqi, T.O. (2012) Effect of gamma radiation on morphological, biochemical, and physiological aspects of plants. Environ. Rev. 20, $17 \mathrm{e} 39$.

Jayeraman, J. (1985) "Laboratory Manual in Biochemistry", Willy Eastern Limited, New Delhi.

Ji, L., Wu, J. and Gao, W. (2011) Antioxidant capacity of different fractions of vegetables and correlation with the contents of ascorbic acid, phenolics, and fl avonoids. J. Food Sci. 76, C1257-C1261.

Jimenez, L., Alarcon, E. and Trevithick-Sutton, C. (2011) Effect of gamma-radiation on green onion DNA integrity: Role of ascorbic acid and polyphenols against nucleic acid damage. Food Chem. 128, 735-741.

Kim, J.K., Jo, C. and Hwang, H.J. (2006) Color improvement by irradiation of Curcuma aromatica extract for industrial application. Radiat. Phys. Chem. 75(3), 449-452.

Lee, Y.M., Jeong, H.J. and Na, H.J. (2001) Inhibition of immunologic and non-immunologic stimulationmediated anaphylactic reactions by water extract of white eggplant (Solanum melongena). Pharmacol Res. 43(4), 405-409.

Manz, B., Muller, K. and Kucera, B. (2005) Water uptake and distribution in germinating tobacco seeds investigated in vivo by nuclear magnetic resonance imaging. Plant Physiol. 138, 1538e1551.

Marinova, D., Ribarova, F. and Atanassova, M. (2005) Total phenolic and total flavonoids in Bul-garian fruits and vegetables. J. Chem. Techn. Metall. 40(3), 255-260.

Mohajer, S., Taha, R., Lay, M. Esmaeili, A. and Khalilia, M. (2014) Stimulatory effects of gamma irradiation on phytochemical properties, mitotic behavior, and nutritional composition of sainfoin (Onobrychis viciifoliaScop.). Sci World J. Volume 2014, Article ID 854093, 9 pages, http://dx. Doi. org/10.1155/2014/854093.

Nagarajan, D. and Ramesh Kumar, T. (2017) Fourier transform infrared spectroscopy analysis of garlic (Allium). Int. J. Zool. Stud. 2(6), 11-14. 
Neto, A.D.A., Prisco, J.T. and Gomes-Filho, E. (2009) Changes in soluble amino-N, soluble proteins and free amino acids in leaves and roots of salt stressed maize genotypes. J. Plant Interactions, 4(2), 137-144.

Ojiewo, C.O., Agong, S.G. and Murakami, K. (2005) Male- sterility Induced by $\gamma$-ray Irradiation of African nightshade (Solanum nigrum L. ssp. villosum) seed. J. Hortic. Sci. Biotech. 80, 699-704.

Oktay, M., Küfrevioğlu, I. and Kocaçalışkan, I. (1995) Polyphenoloxidase from amasya apple. J. Food Sci. 60(3), 494-496.

Oufedjikh, H., Mahrouz, M. and Amiot, M.J. (2000) Effect of g-irradiation on phenolic compounds and phenylalanine ammonia-lyase activity during storage in relation to peel injury from peel of Citrus clementina Hort. Ex. Tanaka. J. Agric. Food Chem. 48, 559-565.

Pereira, E., Barros, L. and Antonio, A.A., et al. (2015) Analytical methods applied to assess the effects of gamma irradiation on color, chemical composition and antioxidant activity of Ginkgo biloba L. Food Anal Methods, 8, 154-163.

Price, M.L., Van Scoyoc, S. and Butler, L.G. (1978) A critical evaluation of the vanillin reaction as an assay for tannin in sorghum grain. J. Agric. Food Chem. 26, 1214-1218.

Rahimi, M.M. and Bahrani, A. (2011) Effect of gamma irradiation on qualitative and quantitative characteristics of canola (Brassica napus L.). Middle East J. Sci. Res. 8, 519-525.

Shahidi, F. and Naczk, M. (1995) Methods of analysis and quantification of phenolic compounds. In: "Food Phenolic: Sources, Chemistry, Effects and Applications". Technomic Publishind Company, Inc: Lancaster, $287 \mathrm{p}$.

Sharififar, F., Dehghn-Nudeh, G. and Mirtajaldini, M. (2009) Major flavonoids with antioxidant activity from Teucrium polium L. Food Chem. 112(4), 885888.

Shrivastava, A., Srivastava, N. and Kumar, N. (2012) Phytochemical screening and study of analgesic activity of brinjal leaves. Pharma Sci. Mon. 3, 0283033.
Silva, J.M., Silva, J.P. and Spoto, M.H.F. (2007) Análises fisiológicas e enzimáticas em abacaxi submetido à tecnologia de radiação ionizante. Ciênc Tecnol Aliment. 27, 602-607.

Singh, A.P., Luthria, D. and Wilson, T. (2009) Polyphenols content and antioxidant capacity of eggplant pulp. Food Chem. 114(3), 955-961.

Sobhy, M., Abdalla, M. and Ammar, S. (2009) Total phenolic contents and antioxidant activity of corn tassel extracts. Food Chem. 112, 595-598.

Taher, D., Solberg, S. and Prohens, J. (2017) World Vegetable Center Eggplant Collection: Origin, Composition, Seed Dissemination and Utilization in Breeding. Front Plant Sci. 8, 1484.

Taoutaou, A., Socaciu, C. and Pamfil, D. (2010) Fouriertransformed infrared spectroscopy applied for studying compatible interaction in the pathosystem phytophtora infestans-Solanum tuberosum. Not. Bot. Horti. Agrobot. Cluj. 38(3), 69-75.

Tekam, M.L., Desire, T.V., Marius-Nicusor, G., Maria, Z.M., Emmanuel, Y. and Akoa, A. (2014) Differential responses of growth, chlorophyll content, lipid peroxidation and accumulation of compatible solutes to salt stress in peanut (Arachis hypogaea L.) cultivars. Afr. J. Biotechnol. 13(50), 4577-4585.

Thapa, C.B. and Jacks, A.B. (1999) Effect of acute exposure of gamma rays on seed germination of Pinus kesiya Gord and P. wallichiana. Bota Orient J. Plan Sci. 2, 120-121.

Variyar, P.S., Limaye, A. and Sharma, A. (2004) Radiation-induced enhancement of antioxidant contents of soybean (Glycine $\max$ Merrill). $J$. Agric. Food Chem. 52, 3385-3388.

Yu, K., Zhu, K., Ye, M., Zhao, Y., Chen, W. and Guo, W. (2016) Heat tolerance of high bush blueberry is related to the antioxidative enzymes and oxidative protein-repairing enzymes. Sci. Hortic. 198, 36-43.

(Received 26/2/2019; accepted 8/5 /2019) 


\section{التأثثر المحفز لاشععه جاما على المركبات النباتيه للباذنجان}

امينه عبد الحميد، نهي عيد عليوه، محمد حسن محمد عبد المجيد

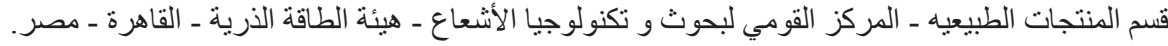

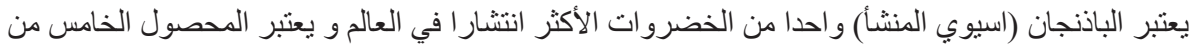

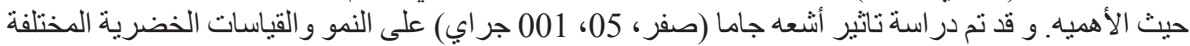

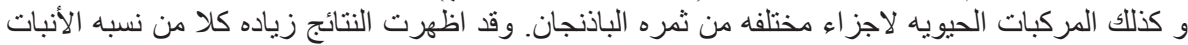

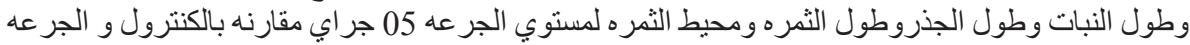

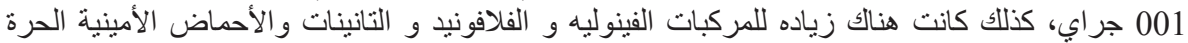

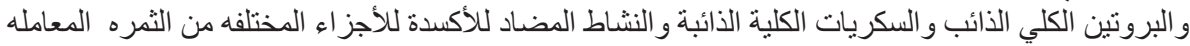

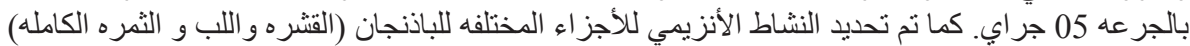

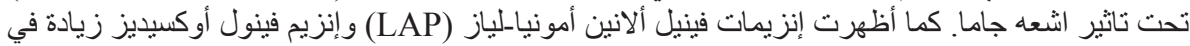

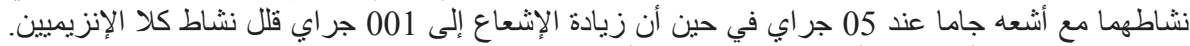

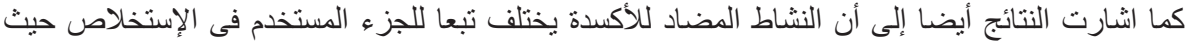

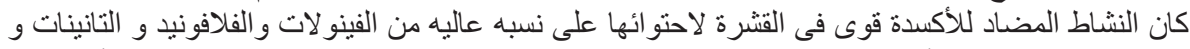

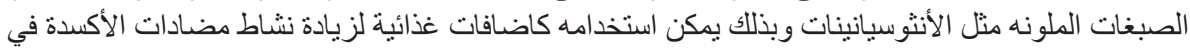

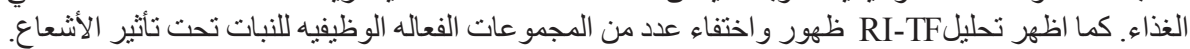

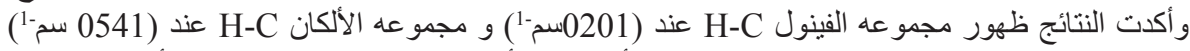
و ومجو عه الدهون عند (0541 سم-1) و مجمو عه الأحماض الأمينيه عند (93.0493 سم-1) للأجز اء المختلفه 